\title{
THE SIEGE ON NIGERIAN TOWNS: REFLECTIONS ON THEPROBLEM OF RURAL-URBAN MIGRATION
}

\author{
C. O. Ikporukpo, \\ University of Ibadan, \\ Ibadan,
}

The rate of urbanization in Nigeria, as it is true of most developing is considerable. This is true not only of the increase in the; of urban centres over time but also the rate of population in individual towns. In 1921 there were 29 urban centres of 10.000 people, accounting for $7.2 \%$ of the country's population. Though the number of urban centres decreased slightly to 27 in, 1931, by 1952 this number had increased to 56 and to as many as 180 in 1983 . These towns had in them $7.2 \%$ of the population in $1931,10.6 \%$ in 1952 and 19.1 in 1963 (Mabogunje, 1974a). According to the Research Planning Committee of the Nigerian Geographical Association (1989) there are now (in 1989) 384 urban centres accounting for about $30 \%$ of the country's population.

In spite of the significance of the number of towns, the rapid population growth in individual urban centres is perhaps a more revealing phenomenon. This is particularly true of the federal and the state capitals and the major industrial centres. For instance, Lagos, with a population growth rate of about $13.6 \%$ per annum, is one of the fastest growing cities in the world. This growth rate is about five times the national. Its population increase from about 28,500 in 1871 through 0.7 million in 1963 to about 8 million in 1985 (Nwafor 1982, Master Plan of Lagos, 1985). Indeed, by 1995, according to a United Nations estimate, it is expected to be the 35th most populous city in the world and the 30th in the year 2000 (United Nations, 1985).

One interesting aspect of the rapid growth in the population of the urban centres is that it is due not to natural increase but to net migration. One estimate by the U.N. indicates that between 1966 and 1975, 59\% of the growth in the population of Lagos was due to net migration. It is possible that this is an under -estimate, for, even by 1931, the only census for which data on place of birth are available, more than $55 \%$ of the inhabitants of Lagos were born outside the city. How important migration has been becomes more obvious when the Lagos situation is compared with that of cities in the developed world. For instance, between 1962 and 1968 only $41 \%$ of the increase in the population of Paris was due to net migration while the corresponding figure for Tokyo between 1970 and 1975 was 30\% (United Nations, 1982). 


\section{Annals of the Social Science Council of Nigeria}

This massive movement into Nigeria's urban centres could-be linked to a siege, with the invaders, though unarmed, creating more or less emergency situations. Why do people move to these urban centres? What effect does such movement have on the towns and the rural areas? What attempts have been made to check such movement? How meaningful have such attempts been? What is the way forward? It is these issues that I shall now go on to examine.

\section{Factors of Rural-Urban Drift}

The spate of rural-urban migration is basically the result of "push" conditions in the rural areas and ones of "pull" in the towns. In other words it is consequent on rather unfavourable conditions in the rural areas and relatively more favourable ones in the towns.

One important dimension of these conditions is the marked disparity in development between the towns and the villages. Not only are the urban areas almost the exclusive centres of industry and commerce but also of social infrastructure. There is clearly a concentration of industries in a few urban centres. This is a situation that has persisted since the early years of industrialization in the country. For instance, in 1965, the major urban centre s of Greater Lagos, Kano, Kaduna, Port-Harcourt, Warri/Sapele, Ibadan, Aba, Zaria, Jos and Abeokuta accounted for more than $80 \%$ of the total number of industrial plants in the country. This percentage increased to more than 90 in $1 \% 9$. Indeed, Greater Lagos alone accounted for more than 37\% of the total in 1965 and 50\% in 1969 (Ayeni, 1981; Green 1977). There are indications that such a highly concentrated pattern has continued into the present.

Apart from being centres of industrial employment, the urban centres, especially the capital cities, are also usually the Seats of various government establishments. The sum total of this concentration of industrial and administrative functions is that commercial activities tend to gravitate towards these centres. Given these characteristics of the towns, it is to be expected that it is they that job seekers will move to.

The attraction of the urban centres is further enhanced by the presence of various facilities which are not available in most rural areas. These include educational, especially secondary and tertiary, health and communication facilities, among others. The situation in Kano State in the early 1970s, one which may not have changed significantly, at least in terms of proportions, provides a dramatic expression of the urban rural contrast. Then, whereas the metropolis had 16 post-primary and 2 post-secondary institutions, the other rural parts of the State, the total area of which was more than 530 times the size of the city and about 18 times the population, had only 11 post-primary schools. The city 
The Siege on Nigerian fawns:., 25

had 4 hospitals including one specialist and several private clinics, while the other parts had only one. The corresponding figures for banks are 11 and 1, for cinema houses 7 and 2 and for post-offices 4 and 1. Furthermore, whereas there was electricity supply in all parts of the metropolis, only two other centres had. Similarly, the metropolis had 105 wholesale establishments/distribution firms while the other parts had only 8 (Filani, 1981).

This disparity in development is to a large extent a reflection of government policies and action. The distribution of planned public sector investment between the two areas in the First to the Third National Development Plans, shown in Tables 1 to 3, is a clear indication of this. In none of the sectors, except community development (in the Third Plan) is .the allocation to the .rural areas comparable to that of the urban. For instance, the allocation to the urban areas in the industrial and communication sectors in the First and Third Plans, accounted for more than $90 \%$ of the total allocation to each of the sectors. Indeed all the allocations to communication in the second Plan' and to housing, sewage/drainage and labour in the Third Plan were for the urban areas.

Table 1: Planned Rural-Urban Distribution of Government Investment in the National Development Plan (1962-68).

\begin{tabular}{lllc} 
Sector & Rural & Urban & Rural-Urban \\
Trade and Industry & 2.6 & 97.1 & 0.3 \\
Electricity & 0.6 & 97.9 & 1.5 \\
Communications & 0.0 & 91.4 & 8.6 \\
Health & 3.9 & 76.2 & 19.9 \\
Information & 0.0 & 37.8 & 62.2 \\
Social Welfare & 9.2 & 90.8 & 0.0 \\
Water Supply & 39.6 & 58.5 & 1.9 \\
\multicolumn{1}{c}{ TOTAL } & $4.9 \mathrm{~b}$ & $91.7 \mathrm{~b}$ & $3.4 \mathrm{~b}$
\end{tabular}

a. Under this heading are public expenditure items whose benefits could not be disaggregated in rural and urban components.

b. This is a weighted average with the proportionate allocations to the various sectors as the weights.

Source: Okowa (1987).

Whereas the need for employment and the desire to enjoy the social facilities not available in most rural areas may encourage movement into the urban centres, these in themselves may not necessary lead to such drift. One factor which reinforces those discussed earlier and which is increasingly becoming important*, is that of rising expectation. This is particularly true of young school leavers who perceive move- 


\section{Annals of the Social Science Council of Nigeria}

Table 2: Planned Rural-Urban Distribution of Government Investment and Expenditure in the Second National Development Plan (1970-74).

\begin{tabular}{|c|c|c|c|}
\hline Sector & Rural & Urban & Rural-Urban $^{\mathrm{a}}$ \\
\hline Industry & 47.0 & 53.0 & 0.0 \\
\hline Commerce and Finance & 16.0 & 84.0 & 0.0 \\
\hline Electricity & 11.0 & 89.0 & 0.0 \\
\hline Communications & 0.0 & 100.0 & 0.0 \\
\hline Health & 6.6 & 43.1 & 50.3 \\
\hline Information & 0.0 & 53.9 & 46.1 \\
\hline Labour and Social Welfare & 28.2 & 66.1 & 5.7 \\
\hline Water and Sewage & 14.7 & 60.8 & 24.5 \\
\hline Town \& Country Planning & 9.1 & 81.4 & 9.5 \\
\hline TOTAL & $8.0^{\mathrm{b}}$ & $79.6^{\mathrm{b}}$ & $12.4^{\mathrm{b}}$ \\
\hline
\end{tabular}

a. Same as in Table 1.

b. This is a weighted average with the proportionate allocations to the various sectors as the weights.

Source: Same as Table 1.

Table 3: Planned Rural-Urban Distribution of Government Investment in the Third National Development Plan (1975-80).

\begin{tabular}{|c|c|c|c|}
\hline Sector & Rural & Urban & Rural-Urban $^{\mathrm{a}}$ \\
\hline Industry & 3.4 & 96.7 & 0.0 \\
\hline Commerce and Finance & 4.9 & 86.7 & 8.4 \\
\hline Electricity & 21.9 & 78.1 & 0.0 \\
\hline Communications & 0.1 & 97.5 & 2.3 \\
\hline Health & 13.3 & 50.0 & 36.6 \\
\hline Information & 0.0 & 67.4 & 32.6 \\
\hline Social Welfare & 0.4 & 68.3 & 31.3 \\
\hline Water and Sewage & 23.6 & 68.2 & 8.2 \\
\hline Sewerage \& Drainage & 0.0 & 100.0 & 0.0 \\
\hline Town \& Country Planning & 2.5 & 88.7 & 8.8 \\
\hline Co-operative \& Supply & 9.9 & 16.5 & 73.6 \\
\hline Community Development & 74.2 & 7.0 & 18.7 \\
\hline Labour & 0.0 & 100.0 & 0.0 \\
\hline Housing & 0.0 & 100.0 & 0.0 \\
\hline General Administration & 0.7 & 84.5 & 14.8 \\
\hline Defence \& Security & 0.0 & 39.0 & 61.0 \\
\hline TOTAL & $4.1^{\mathrm{b}}$ & $78.4^{\mathrm{b}}$ & $17.5^{\mathrm{b}}$ \\
\hline
\end{tabular}

a: Same as in previous tables.

b: This is a weighted average with the proportionate allocations to the various sectors as weights.

Source: Same as Table 1. 
ment to the urban centres as the only channel for satisfying their economic- and other goals. This is because most of these individuals perceive farming as an occupation for the illiterate, given the "drudgery in farm work and low returns from agriculture" (Federal Republic of Nigeria, 1975, p. 66). There is no doubt that the wage/income differentials between the rural areas and the urban centres especially in the 1970s and early 80s and the demonstration effect of the urban way of life seem to have heightened this expectation.

Having examined the basic causes of rural-urban drift, it is necessary to discuss the impact of this phenomenon.

\section{Effects of Rural-Urban Migration}

The drift to the urban areas affects the economy and society of both the rural sources and the urban destinations. This dual impact has been aptly stated by the Federal Government (1981, p. 362) thus:

Nigerian has in recent years experienced a very rapid rate of rural-urban migration. . . The adverse effects of this development on agricultural production and the urban environment are quite glaring. Agriculture is suffering from an acute shortage of labour, making it difficult to expand the area under cultivation, while in the towns and cities, the supply of social and infrastructural facilities e.g., housing, water, health services, etc. have come under severe pressure.

\section{Impact on Rural Areas}

The shortage of agricultural labour in the rural areas is particularly complex because of the age and sex-selectivity in migration. Usually it is the young, active and better educated population between the ages of 14 and 45 years that has the greatest propensity to migrate. Similarly, males tend to migrate more than females. A study on Lagos (Afolayan, 1985) has shown that of a sample of 519 migrants, $74.3 \%$ were aged 24 and below at the time they arrived in Lagos. Indeed about 93\% were aged 34 and below. Similarly, the males and the literate moved more frequently than the females and the illiterate. The implication of such a movement pattern is that tasks, such as agriculture and construction, which are usually performed by the active population, suffer. In situations where hired labour is available, such is usually costly and beyond the reach of many. It may be argued that in areas such as in parts of the Eastern States where farmland is in short supply, with a consequent increasing pressure of population on land, such rural-urban migration could be advantageous. This argument cannot however be stretched too far given the age and sex-selective nature of migration and land tenure problems. 


\section{Annals of the Social Science Council of Nigeria}

The depopulation of the rural areas consequent on migration works more or less in a vicious circle. The low 'population means the threshold necessary for an economic provision of public facilities may not be attained in individual settlements. Furthermore, the depressed average income consequent, on reduced economic activities may limit the number of people capable of paying for public facilities provided. The implication of all this is that the public facilities may not be provided and this may result in a further depopulation of rural centres. Whereas usually the non provision of such facilities is seen as one of the factors in migration, it is sometimes argued that the provision of such facilities as good roads instead of dampening migration encourages it. The reasoning is that the improved access may increase interaction between the rural areas and the urban centres and in the process increase the expectation and the yearning for the urban way of life.

In spite of these adverse effects of migration on rural areas, these areas sometimes benefit from monetary remittances and community development efforts by migrants. It is known that many migrants maintain links with their source areas and more often than not send money home periodically to their dependants and aged relations. It is therefore reasonable to argue that at the individual level many people in the rural areas may have been worse off but for the incidence of migration. This is particularly so since urban wages/incomes are generally higher than the rural ones which individuals might have earned if they did not migrate. Of more significance however, are the various self-help projects such as schools, markets and postal facilities financed by such migrants. Be this as it may, the disintegration of social units which goes with migration could sometimes have traumatic effects on dependent relatives left behind.

\section{Impact on urban centres}

The many problems of the urban centres, which have resulted from the increasing population pressure, consequent mainly on rural-urban drift, can be categorized into four dimensions. These are unemployment, liveability, serviceability and manageability (Mabogunje, 1974b).

Many individuals migrating into the cities do not have any specialized skills. Indeed many of them are either drop-outs of primary and secondary schools or graduates of these schools. Some have even not obtained any formal education. Thus, lacking any formal skills, many of the migrants are unemployable. Even those who have such skills may not necessarily get employed, given the number of people looking for the comparatively few openings. The result is the high rate of unemployment in the cities. For instance, the Labour Force Sample Survey of 1966/67 indicated an urban unemployment rate of $8.9 \%$ compared with a national average of $1.7 \%$ and a rural rate of $0.5 \%$ (Mabogunje, 
The Siege on Nigerian Towns:... 29

1974a, Ojo, 1977). The r.ate was much higher in the large urban centres. For instance, the rate was $18 \%$ in Lagos, $17.4 \%$ in Ibadan, and $11.5 \%$ in both Port Harcourt and Enugu, The national urban unemployment rate in 1974 was $6.4 \%$ with a rate of $7.2 \%$ in Lagos, $11.5 \%$ in Enugu and $13.3 \%$ in Port Harcourt. In 1976, a town such as Calabar had a rate of $13.5 \%$ (Ojo, 1977). There is no doubt that with the present economic problems of the country the unemployment rate in many of the urban centres is likely to be phenomenally high.

One consequence of this high unemployment rate is the high rate of-crime in the dues. For instance, in Kaduna 794 cases of crime were reported to the Police in 1981. The number was 700 in 1982, 725 in 1983 and 734 in 1984. In 1984, 784 people were awaiting trial (Onibo-kun, et al., 19.86).

The issue of liveability pertains to the low levels of environmental quality and housing, and transportation facilities provision. One important dimension of the environmental problems facing the cities is that of solid wastes. In most cases, the rate" at which solid waste is being generated far out-strips the disposal capability. The result is the unsightly heaps of solid waste found in many Nigerian towns. One census of such heaps in 15 Nigerian towns in 1983 (see Abumere 1983) identified 118 in Lagos, 104 in Ibadan, $99 \mathrm{~m}$. Port Harcourt, 92 in Kano, 83 in Aba, 81 in Onitsha, 51 in Potiskum, 50 in Kaduna, 48 in Uyo, 32 in Warri, 24 in each of New Bussa and Jos, 20 in Gusau, 17 in Suleja and 10 in Oshogbo. In many of these cities such as Ibadan many roads are usually virtually taken up by such waste.

The housing problem manifests itself not only in terms of the many homeless poor but also in overcrowding, excessive rents, and inadequate or, in certain cases, total absence of infrastructural facilities. Nevertheless, "the main problem in the housing sector is the inadequacy of

Table 4: Housing Conditions in Selected Nigerians Towns

$\begin{array}{llllll}\text { Town } & \begin{array}{l}\text { \%of } \\ \text { Households } \\ \text { occupying } \\ \text { one room }\end{array} & \begin{array}{l}\text { Average } \\ \text { No. of } \\ \text { persons } \\ \text { per room }\end{array} & \begin{array}{l}\text { \%of } \\ \text { tap water with }\end{array} & \begin{array}{l}\text { \%of } \\ \text { touses with } \\ \text { flush toilet }\end{array} & \begin{array}{l}\text { \%ouses } \\ \text { with } \\ \text { electricity }\end{array} \\ \text { Lagos } & 72.5 & 3.8 & 71.7 & 43.5 & 93.2 \\ \text { Port Harcourt } & 51.5 & 2.4 & 75.0 & 18.6 & 81.4 \\ \text { Benin } & 48.0 & 2.2 & 24.9 & 4.0 & 59.3 \\ \text { Warri } & 59.9 & 2.6 & 62.4 & 10.9 & 89.7 \\ \text { Kaduna } & 63.9 & 2.1 & 40.3 & 14.1 & 53.3 \\ \text { Kano } & 69.1 & 2.4 & 26.1 & 1.8 & 69.1 \\ \text { Dorin } & 23.9 & 1.6 & 30.7 & 10.3 & 28.4 \\ \text { Ibadan } & 47.3 & 2.1 & 33.4 & 25.2 & 56.1\end{array}$

Source: Federal Republic of Nigeria, 1975, p. 307. 
the existing housing stock and the slow rate of housing production" (Federal Republic of Nigeria, 1981, p. 340). Table 4 gives an indication of the dimension of the problem. For instance, about $73 \%$ of the households in Lagos occupied only a room, with the average number of persons per room being 4. Many of the houses in the towns did not have any tap water, flush toilet and even electricity supply. A more recent survey of the sprawling areas of Ibadan (see Onibokun, et al., 1986) shows that only about 11\% of 302 sampled houses had tap water supply while those with electricity supply made up about 55 per cent. In the various towns, the attempt to provide more houses as quickly as possible has resulted in the development of slums.

The provision of transport infrastructure in most of the towns has also not kept pace with the increase in population. Without any exception, all Nigerian towns, especially the large ones, lack an effective public transport system. Scenes of large crowds in bus-stops waiting on end for the relatively few buses are a common sight. Furthermore, the large number of private cars and the low capacity of many city roads had resulted in tedious traffic jams in most cities. Nowhere are these problems more glaringly demonstrated than in Lagos, the capital and the most industrialized city in the country. The number of new vehicle registered in the city rose from about 17,000 in 1971 to about 72,000 in 1982. In 1976 there were about 100,000 vehicles in circulation within the city in a given day; this increased to about 200,000 in 1982 . Thus during peak hours, it takes about $1 \frac{1}{2}$ to 2 hours to move a distance of only 15 to $20 \mathrm{~km}$ (Bolade, I986).

The problem of serviceability has to do with the inability of the urban welfare facilities such as educational and health amenities to serve the needs of a rapidly increasing population. As the government rightly pointed out "the development of. . .electricity, water supply, and other essential urban infrastructure has not kept pace with population growth and these facilities have consequently come under severe pressure in the face of rapid urban growth in recent years" (Federal Republic of Nigeria, 1975,-p. 313). Chronic water shortage and frequent cut in electricity supply are a result of this pressure on urban facilities..Indeed in some cities such as Ibadan, taps in some areas may be dry for months on end. Other facilities such as health and educational ones are also subjected to a lot of pressure with a consequent deterioration in the quality of service.

These various problems consequent on the phenomenal growth in cities are particularly prominent because of the generally poor quality of urban management. Generally, the ability to manage city activities and the capacities to anticipate future changes are low. These short comings contribute immensely to the disorderly development and the 
The Siege on Nigerian Towns,... 31

inefficient delivery of city services. The Federal Government did not mince its words on this when it declared:

the lack of effective planning and administrative machinery tor physical phoning, the provision of basic utilities and facilities, and environmental control of the urban centres leaves a gap in service delivery. In addition, there is the inadequacy of building statutory regulations and legal sanctions to' induce discipline and order in the pattern of human settlement (Federal Republic of Nigeria, 1981, p. 348).

Given the causes and the effects of the drift to the urban centres, what attempts have been made by government to handle this problem?. This is the issue that is examined next.

\section{Combative Measures by Government}

The main thrust of government policy on checking and managing the drift to the urban centres has been aptly summarised in the Fourth Plan document thus:

Government fully appreciates the existing maldistribution of population in favour of the urban centres and the problems it is posing for both the urban and the rural economy. Given our democratic political system however, government cannot hope to tackle the problem by curtailing the freedom of movement of citizens. As a practical alternative, government will pursue a policy of integrated urban and rural development. . -the strategy will seek to raise the level of economic activity in the rural sector and particularly in agriculture quite significantly and to improve the quality of life in the rural areas by providing essential economic and social infrastructure e.g., water, electricity, health services, etc, so as to weaken the pull exerted on rural communities by the urban centres" (Federal Republic of Nigeria, 1981, p. 365)

Government policies and programmes for developing rural areas and consequently checking the drift to the urban centres may be divided into three categories. These are those that lay emphasis on employment generation, policies and programmes for social and economic infrastructure development and lastly, those on an integrated development of rural areas. These are discussed in turn.

\section{Employment Generation as a Check}

The earliest conceptualisation of a check for rural-urban population drift was in terms of reducing the drudgery involved in farming and increasing productivity thereby making agriculture more attractive. This may make more people interested in agriculture and hence the employment generation potentials of the rural areas may be increased.

Whereas there have been several agricultural programmes in the country, only those which have elements specifically meant to check, rural-urban migration are discussed here. One of the best known of such 
programmes is the farm settlement scheme which was first introduced in the then Western Region and had as one of its objectives the pro vision of employment for primary school leavers as an alternative to migration to urban areas especially since basic amenities were provided in these settlements (Bath and Adeogun, 1966; Rogge, 1977). In the West, F.A.O. experts headed by Israeli planners supervised their introduction in 1959. By 1964, about 20 settlements had been established ${ }^{\wedge}$ with the number of settlers ranging from 56 in Ogbomosho to 300 at Ado-Odo. The scheme in the East was largely influenced by that in the West and was modelled after that (Floyd and Adinde, 1967). In spite of the high hopes on the farm settlement schemes, these did not in any way check the drift of young school leavers. There was a general dissatisfaction with the regimented life in the settlements with a consequent high rate of desertion. The failure of the farm settlement schemes showed clearly how difficult it could be to make agriculture attractive as an employment avenue for young school-leavers.

The development of small scale industries which are capable of generating employment in rural areas has also been seen as an approach to the "mitigation of ruralurban migration" (Federal Republic of Nigeria, 1975, p. 155). This according to the Federal Government could be achieved through incentives meant to provide complementary assistance in financial, management and technical aspects of business. The Industrial Development Centres and the Small-scale Industrial Credit Schemes of the States are the main vehicle for administering the incentives. In spite of the fact that in most cases, the raw material needs of such industries could readily be satisfied by rural resources, the lack of supporting infrastructure for industries drastically reduces the attraction of these rural areas. Thus it is not uncommon to find in many urban centres small-scale industries which should ideally be in "rural areas. What is more, there is usually a wide gap between intent and actual implementation.

\section{Check through infrastructure provision}

In spite of the fact that some rudimentary infrastructure was' provided in the farm settlement schemes, these settlements cannot in themselves be regarded as examples of a "migration dampening through infrastructure provision strategy." This is particularly the case because these schemes did not provide such facilities in already existing rural settlements but in the confines of new locations designated as the farm settlement sites.

A number of more or less unconnected government schemes on the provision of these social and economic infrastructures together make up this strategy for checking migration. One usual argument that underlies these schemes is the need to make the rural areas more attractive. Some 
The Siege on Nigerian Towns:... 33

of these schemes include rural electrification schemes, water supply schemes and the rural banking programme. For instance, the rural banking programme of the Federal Government, initiated in 1977. Involves the mandatory establishment of rural branches by banks operating in the country. It is divided into three phases: 1977-1980, 19811983 and 1985-1989. The first phase involved the sitting of 200 branches while the second and the third entail 266 and 300 branches respectively (Agbola, 1987). There is no doubt that the mere provision of such infrastructure without the necessary employment avenues can not in any ways check migration since the need to improve oneself economically is usually the major motive for migrating. The major problem has, however, been one of implementing these schemes meant for the rural areas.

\section{Integrated Rural Development as a Check}

The realization that the problem of rural-urban migration and indeed rural development could best be handled through an "integrated" rather than a disjointed approach first emerged in the Third National Development Plan period with the Integrated Rural Development Projects (IRDPs). This realization was properly articulated in the Fourth Plan. According to the Plan, integration was to be achieved through the Agricultural Development Programme (ADP) and the Accelerated Development Areas (ADAs). Both programmes are concerned with the facilitation of rural economic activity. The ADP combines agricultural production with the provision of economic and social infrastructure such as roads, schools, hospitals, housing, etc. The ADA programme involved the construction of feeder roads and generally laying a solid, foundation for the take-off of ADP where it was yet to start.

The IRDPs, begun in 1975 at Funtua, Gombe and Gusau have a number of core elements. These are, an efficient input delivery and; credit supply system, such that no farmer travels more than $15 \mathrm{~km}$ to get inputs; a massive rural feeder road system that facilitates input delivery and produce evacuation; an effective extension and training scheme and solid project management together with monitoring and', evaluation (Idachaba, 1980). The scheme is funded by the World Bank, and the Federal and State governments. The details of operation of the scheme vary from one project to another; so also is the area covered.

The programme of the River Basin Authorities established in 1976 and subsequently renamed River Basin and Rural Development Authorities'(RBRDAs), is also largely based on the idea of integrated development. Eleven of these Basin Authorities covering all parts of the country were initially established. They are meant to tap the development potentials of their areas of operation and also control floods. 


\section{Annals of the Social Science Council of Nigeria}

erosion and pollution. These land and water resources development authorities, are given comprehensive powers for agricultural and integrated rural development. The details of approach used, vary from one RBRDA to another. One RBRDA that clearly conceptualized its approach is Benin-Owena. The Authority's Village Projects System (VPS) involves village cooperatives, direct production, community effort, homesteading, farmer participation, corporate firm effort and religious group effort in integrated rural development schemes (Eweka, et al, 1979). In the area of agriculture, the RBRDA either gives supportive facilities, produce directly or use the mechanism of participatory small hold farmers operating on partially mechanised and irrigated farms such as the case of the Hadejia-Jamaare RBRDA.

In spite of the integrated nature of the Agricultural Development Projects and the RBRDAs, their potentials for checking the drift from, the rural areas seem limited. This is because they are based on the assumption that agriculture is capable of satisfying the employment needs of rural dwellers. Given the way agriculture is perceived by young school-leavers, this may not be. Furthermore in the case of the RBRDAs, there has been a marked shift in practice from the ideal of integrated development. They have become organs of sectoral (especial water resources and irrgation farming) development (Areola, 1982).

The programme of the Directorate of Food, Roads and Rural Infrastructures (DFRRI) contains the essential elements necessary to check the problem of rural-urban drift. This is because it not only provides the social and economic infrastructure necessary to make the rural areas attractive but also diversifies the employment base of rural areas through agricultural and cottage and small scale industrial development.

The programme launched in 1986, has "as part of its conceptual framework, a moral, social, cultural, economic, security, and social mobilisation logic" (Federal Republic of Nigeria, 1987). Within this framework, food and agriculture, handicrafts, cottage and small-scale industries, rural health, rural infrastructural development, rural socio-cultural development, grassroots sports development, and political development and social mobilisation are regarded as the essential contents of the programme.

The development strategy of- the DFRRI relies on a proper organisation of space and of people (see Federal Republic of Nigeria, 1986) Three levels of community organisations are recognised. These are the primary production centres/units, the higher production/development centres and the development areas. The primary production centre is made up of not less than one hundred families with a minimum of 500 hectares available for production. The higher production centre is made up of several primary production centres, such that each Local Government Area (L.G.A.) has between three and ten. The development are 
The Siege on Nigerian Towns:... 35

the highest spatial unit, is expected to serve as "the nerve centre" for the economic, sociocultural and political activities its area of influence and 3-7 development areas are recommended for each L.G.A.

The major unit of social organisation for production purposes is the community development association or union. Depending on the wishes people, the association could be based on parts of a village, the whole village or even a clan. Where it is based on a high level unit, there could be decentralised units of the parent body. Each association is the apex organ for deciding on and directing development efforts.

Generally speaking, the implementation of the, programme seems to have fallen short of the conceived ideas. One study (Onibokun, et al., 1988) has indicated that only $31.5 \%$ of respondents in four States (Benue, Imo, Kano and Kaduna) report an improvement in infrastructure and employment consequent on DFFRI's programme. The percentage for Kaduna is 45 but it is as low as 6.2 in Kano. Even for the road programme where as large a percentage as 37 reported an impact; there is usually a wide gap between policy and implementation (Ikporu-kpo, 1988).

\section{Conclusion}

There is no doubt that rural-urban migration has contributed a lot to the ever-increasing population growth in the cities. One basic factor in this migration is the gap in development between the urban and rural centres. In spite of the fact that earlier attempts at checking the problem were rather uncoordinated, the programme of DFRRI provides a good basis for managing it. This suggests that there are apparently meaningful programmes that could reduce the rate of urban drift. What seems to be lacking is the will to implement such programmes. As the Chairman of DFRRI recognized, ". . ,.the problem of this country is not the lack of excellent policy objectives and strategies and well conceptualised and articulated programmes but our inability to convert these into concrete reality. ." (Koinyan, 1987, p. 3). Apart from a proper implementation of such programmes, it is also necessary to evolve an educational system that will make youths realize that agriculture and other rural occupations are not less rewarding economically or less prestigious than urban ones. The new 6-3-3-4 educational system did not perhaps go far enough on this.

\section{References}

Abumere, S.I. (1983) "City surface solid waste in Nigerian/ cities". Environment International, Vol. 19. p. 391-396.

Afolayan, A.A. (1985). "Is there a stepwise Migration in Nigeria' A Case Study of the Migrational Histories of Migrants in-Lagos" Geojournal, Vol. 11, 183-193. 


\section{Annals of the Social Science Council of Nigeria}

Agboola, T. (1987) Financing Rural Infrastructure Development, Paper presented at Workshop on Physical Planning and Rural Infrastructure Development in Nigeria, University of Ibadan.

Areola, O.O. (1982) "Changing Resource Systems and Problems of Development Planning in Nigeria." Resource Management and Optimization, Vol. 2, 41-71. Ayeni, B. (1981) The Spatial Distribution of Manufacturing Industries in Nigeria Technical Report, No. 2, Department of Geography, University of Ibadan, Ibadan.

Bath, W. and O. Ade gun (1966) "Farm settlement scheme of Western Nigeria" Bulletin of Rural Economics and Sociology, Vol. 2, 15-26.

Bolade, A.T. (1986). "Transport in Metropolitan Lagos." Transport Reviews, Vol. 6,1-30.

Eweka, J.A; V.E. Bello-Osagie and S.O. Olayide (1979). Village Development:

Food Basket Management Strategy, Centre for Agricultural and Rural Development, University of Ibadan.

Federal Republic of Nigeria (1975). Third National Development Plan, 1975-80,

Central Planning Office, Lagos. - (1981). Fourth National Development Plan, 1981-85, Lagos.

- (1986). Proposed organization of our Rural communities for increased Productivity and Development, Federal Printer, Lagos.

- (1987). A Possible Way Forward, DFRRI, Lagos.

Filani, M.O. (1981). "Nigeria: The Need to Modify Centre-down Development Planning" in W.B. Stohr and D.R. Taylor (ed.) Development from Above or Below, John Wiley, 283-304.

Floyd, B. and M. Adinde (1967) "Farm settlements in Eastern Nigeria: A Geographical Appraisal" Economic Geography, Vol..43, 189-230.

Green, H.A. (1977). "The Spatial Pattern of' Nigerian Urban Development: Some

Policy Implications" Nigerian Geographical Journal, Vol. 20, 105-121.

Idachaba, F.S. (1980). Concepts and Strategies of Integrated Rural Development: Lessons from Nigeria, Department of Agricultural Economic, University of Ibadan, Ibadan.

Ikporukpo, C.O. (1988) "The Management of the Rural Transportation Problem in Nigeria" Transportation Planning and Technology, Vol. 12, 181-188.

Koinyan, L.D. (1987). The Basis ?/ the People's Programme, DFRRI, Lagos.

Mabogunje, A.L. (1974a) Cities and Social Order, University of Ibadan, Ibadan.

Mabogunje, A.L. (1974b). Towards an urban Policy in Nigeria" Nigerian Journal of Economic and Social Studies, Vol. 16, 85-98.

Nigerian Geographical Association, Research Planning Committee (1989). The Identification, Delimitation and Mapping or Urban Communities in Nigeria, Progress Report, Department of Geography, University of Ibadan, Ibadan.

Nwafor, J.C. (1982). "Urban Settlement Types 4: Metropolitan Lagos" in K.M. Barbour, et al (ed.) Nigeria in Maps, Hodder and Stoughton, Sevenoaks (Kent), 96 and 97.

Ojo, F. (1977). "The urban Unemployment problem" IniKigerianEconomic Society, Urbanization and Nigerian Economic Development, Ibadan, 125-141.

Okowa, WJ. (1987) "Urban Bias, in Nigerian Development Planning" Nigerian Journal of Economic and Social Studies, Vol. 29, 47-59.

Onibokun, P. et al (1986). Urban Growth and Urban Management in Nigeria with Particular Reference to Public Utilities and Infrastructure, Nigerian Institute of Social and Economic Research, (NISER), Ibadan.

(1988). The Directorate of Food, Roads and Rural Infrastructure: An. Assessment of Programmes and Guidelines for the Future, NISER, Ibadan. 
The Siege on Nigerian Towns:... 37

Rogge, J.R. (1977). "Rural Development Problems in Africa: Some Lessons from Western Nigeria": The Canadian Geographer, Vol. 21, 250-267.

United Nations (1982). Estimates and Projections of Urban, Rural and City Populations, 1950202\$: The 1980 Assessment, U.N., New York.

(1985). Estimates and Projections of Urban, -Rural and City Populations, 1950-2025: The 1982 Assessment, U.N; New York. 